\title{
CLIMATE CHANGE AND FISCAL SUSTAINABILITY: RISKS AND OPPORTUNITIES
}

\author{
Matthew Agarwala ${ }^{1,2 *}$, Matt Burke ${ }^{3,4}$, Patrycja Klusak ${ }^{1,4}$, Kamiar Mohaddes ${ }^{5}$, Ulrich Volz ${ }^{6,7}$ and \\ Dimitri Zenghelis ${ }^{1,8}$ \\ ${ }^{1}$ Bennett Institute for Public Policy, University of Cambridge, Cambridge, United Kingdom \\ ${ }^{2}$ Centre for Social and Economic Research on the Global Environment, UEA, Norwich, United Kingdom \\ ${ }^{3}$ Sheffield Business School, Sheffield Hallam University, Sheffield, United Kingdom \\ ${ }^{4}$ Norwich Business School, University of East Anglia, Norwich, United Kingdom \\ ${ }^{5} J u d g e$ Business School \& King's College, University of Cambridge, Cambridge, United Kingdom \\ ${ }^{6}$ Department of Economics \& Centre for Sustainable Finance, SOAS, University of London, London, United Kingdom \\ ${ }^{7}$ German Development Institute, Bonn, Germany \\ ${ }^{8}$ Grantham Research Institute, London School of Economics, London, United Kingdom \\ ${ }^{*}$ Corresponding author. Email: mka30@cam.ac.uk
}

Both the physical and transition-related impacts of climate change pose substantial macroeconomic risks. Yet, markets still lack credible estimates of how climate change will affect debt sustainability, sovereign creditworthiness and the public finances of major economies. We present a taxonomy for tracing the physical and transition impacts of climate change through to impacts on sovereign risk. We then apply the taxonomy to the UK's potential transition to net zero. Meeting internationally agreed climate targets will require an unprecedented structural transformation of the global economy over the next two or three decades. The changing landscape of risks warrants new risk management and hedging strategies to contain climate risk and minimise the impact of asset stranding and asset devaluation. Yet, conditional on action being taken early, the opportunities from managing a net zero transition would substantially outweigh the costs.

Keywords: sovereign debt; climate change; net zero; transition risk; productivity.

JEL codes: H5; H6; H62; J24; N1; Q54; Q55.

\section{Introduction}

Advancements in recent decades in climate science and economic modelling, juxtaposed against the real-time observation of the dire consequences of extreme weather events, have revealed important lessons about the macroeconomic consequences of climate change. These are understood to varying degrees. The best understood lessons include: both the contributions to and consequences of climate change are unequally distributed, estimates of the economic costs of climate change and corresponding uncertainty, tend to grow, rather than fall over time, well-designed carbon pricing mechanisms can effectively reduce emissions and inequality, poorly designed ones do not and it is exceedingly difficult to aggregate from the wealth of climate microeconomic studies to make inferences about macroeconomic outcomes.

Among the less understood lessons are the observation that climate investments are cheaper than the alternative-namely, climate-driven disasters. The effects of climate change are severe even in wealthy countries (Kahn et al., 2021), and the consequences of climate change are landing sooner than 
early models predicted. Many of the biggest risks may fall in the realm of social and political instability rather than extreme weather, and the financial system is far behind and poorly equipped to measure and manage these risks. Recent evidence also shows that many low-carbon and climate resilient investments-from energy and transport infrastructure to buildings and agriculture-are cheaper than their fossil fuel-based counterparts, leading to the potential stranding of the carbon-intensive legacy assets they replace (Office for Budget Responsibility, 2021).

Here, we shed light on the comparatively under-researched question of how climate change might affect the financial system and in particular, fiscal sustainability and sovereign debt markets. First, we provide a taxonomy of how the physical and transition impacts from climate change translate into fiscal risks. Second, we review a small but increasingly urgent literature on how these fiscal risks affect sovereign creditworthiness and the cost of public borrowing, with direct implications for fiscal sustainability. Finally, we demonstrate the taxonomy's usefulness using two examples-one sovereign (the UK) and one industry (renewable energy). Combined, the case studies elucidate two potential uses for our taxonomy, (i) identifying economically relevant blind spots in climate risk analyses and (ii) for understanding feedback mechanisms that must be considered in any attempt to estimate both the costs of decarbonisation and the pace at which it can be achieved. We conclude by reflecting on the types of metrics that could improve the economic assessment of climate risks and how they relate to fiscal decision-making.

Our decision to focus on sovereign debt-even in the midst of a zeal for metrics relating to environmental, social and governance investing-is deliberate. Sovereign debt, which is expected to top $\$ 92$ trillion this year (IIF, 2021) is by far the world's largest asset class. It is the safe haven to which investors flee in times of turmoil, and its sustainability is what determines the capacity of nations to weather shocks, from Covid-19 to climate change.

Whilst climate-economic models have described in ever greater detail the potential costs of the physical impacts of climate change, we highlight the importance of understanding the transition impacts and how they affect fiscal sustainability. Our contribution to this special issue is timely, not just with respect to COP26 in Glasgow, Scotland, but also in the midst of unprecedented fiscal disruption in response to the Covid-19 pandemic. Concern over debt-rollover, fiscal space and the ability to respond to future shocks are now paramount in policy circles. These discussions must include an understanding of how climate change-and our responses to it-will affect the public finances and sovereign debt markets. The topics discussed here are of interest to policy-makers and investors concerned with financial system stability, institutional investors and pension managers, and the flow of accurate information through markets-a necessary condition for the efficient management of risk.

\section{Taxonomy for translating physical and transition risk into sovereign risk}

Although much of the scientific and media attention is understandably focussed on extreme weather events, sea-level rise and ecosystem collapse, there are several transmission channels through which climate change can affect public finances and sovereign risks (see, for instance, Figure 1 and Volz et al., 2020). It is now increasingly recognised that the fiscal consequences of climate change and the policy responses to it are not limited merely to the direct physical damages. ${ }^{1}$ Indeed, some of the most significant near-term impacts on the global economy and public finances, especially in advanced economies, will derive from the climate transition as much as the physical risks from climate change itself. The 'transition' reflects the process of decarbonisation, for example the policies, consumer preferences, litigious actions and technological development that accompany the drive to reduce emissions. Chief among these may be an accelerated pace of human capital obsolescence (and the social disruption this would inevitably bring) as a labour force adapted to the fossil fuel economy struggles to

\footnotetext{
${ }^{1}$ This section builds on Volz et al. (2020).
} 


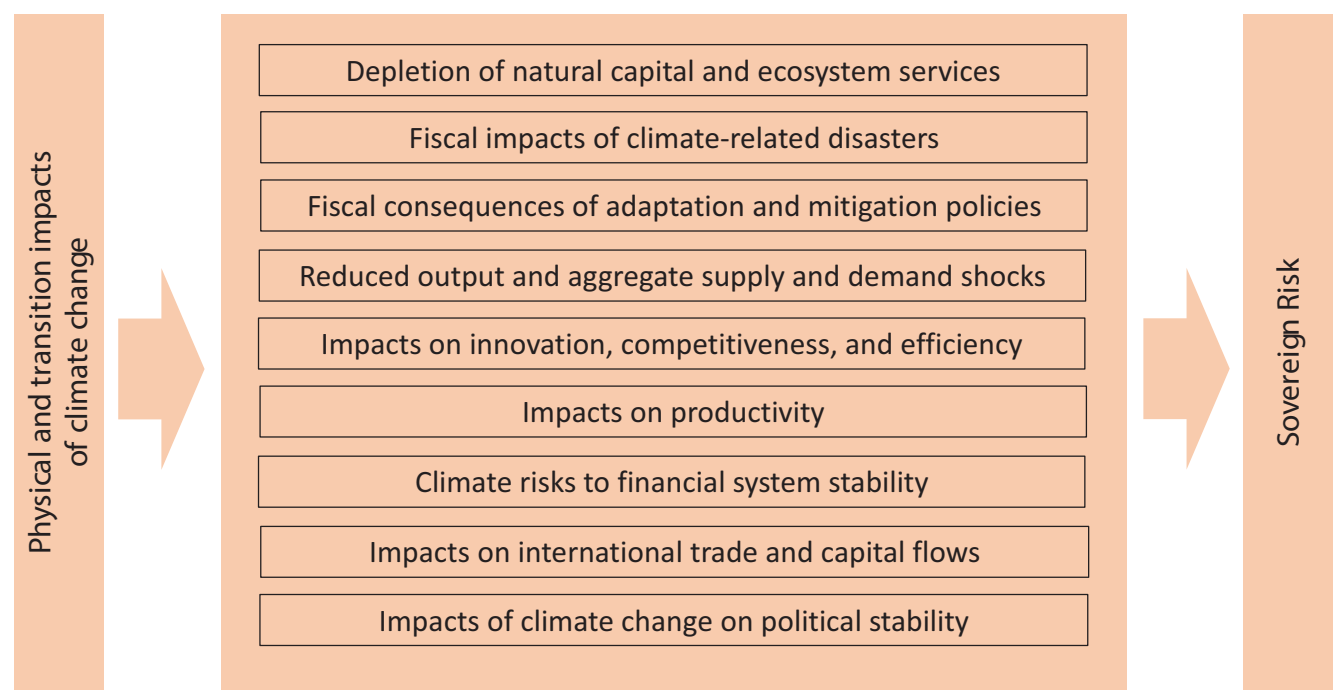

Figure 1. Climate change to sovereign risk: a review of impact pathways. Source: Adapted from Volz et al. (2020).

find productive roles in a low carbon world. As a result, it is important to consider the potential risks and opportunities associated with the structural transformation of the economy.

\subsection{Depletion of natural capital and ecosystem services}

Climate change is expected to have dramatic and adverse effects on natural capital (IPBES, 2019). Traditionally, integrated assessment models (IAMs) such as DICE have modelled climate as an independent feature of nature, ignoring feedback loops with the rest of natural capital (such as biodiversity). In contrast, Bastien-Olvera and Moore (2020) construct a GreenDICE model to simultaneously model these linkages, showing that they have long-lasting implications for human welfare, carbon prices and the optimum investment strategy for addressing climate change. They find that the macroeconomic consequences of emissions are even greater when climate-induced natural capital loss is included and because early investments in biodiversity and ecosystems can partially offset the costs of climate change, they are important components of any climate strategy (Agarwala and Coyle, 2020). The nexus of climate and natural capital has several impacts on sovereign risk, especially for countries in which agriculture, forestry and fisheries are key industries. But it also impacts the frequency, intensity and resilience to extreme weather events such as storm surges, fires, floods and extreme temperatures. The key point is that climate change affects the productive capital stock, output, supply chains and resilience both directly and indirectly through its interaction with other components of natural capital. The associated impacts on the public finances and sovereign risk must be accounted.

\subsection{Fiscal impacts of climate-related disasters}

Public finances and debt sustainability face exposure to different fiscal risks related to climate disasters (Koetsier, 2017). These include both macroeconomic risks and contingent liabilities. Macroeconomic risks related to natural disasters and extreme weather include risks of a disruption of economic activity, which may adversely affect tax income and other public revenues and increase social transfer payments (e.g. Schuler et al., 2019); changes to commodity prices that could affect revenue or increase spending via fossil fuel or food subsidies; effects on inflation and interest rates through supply or demand shocks and 
exchange rate effects (e.g. Farhi and Gabaix, 2016). Contingent liabilities can explicitly or implicitly expose governments to fiscal risks (Mitchell, Mechler, and Peters, 2014; Hochrainer-Stigler et al., 2018; Schuler et al., 2019). Natural disasters may damage or destroy physical government assets and public infrastructure, requiring significant expenditure on relief programmes, damage repair or reconstruction. Indeed, in the United States alone, there have been 298 climate-related disaster events with damages in excess of $\$ 1$ billion since 1980 with a total cost of $\$ 1.975$ trillion in 2021 (NOAA, 2021).

Natural disasters may also affect the assets or operations of state-owned enterprises. Disasters may damage or destroy private property and require government support for households and corporations to rebuild homes and businesses. To the extent that disasters cause instability to the financial sector, they may force governments to bail out ailing financial institutions. Moreover, disasters can cause a severe humanitarian crisis, which may require public emergency measures, including rescue missions, temporary relocation of people, provision of food and shelter or medical treatment. Such crisis response measures can be very expensive and have a significant impact on public spending. ${ }^{2}$ Moreover, economic shocks from extreme weather events, although short term in nature, can also have lasting impacts on growth (Acevedo, 2014; Botzen, Deschenes, and Sanders, 2019; Klomp and Valckx, 2014) and public finances.

\subsection{Fiscal consequences of adaptation and mitigation policies}

The public sector will have to finance a considerable share of adaptation and mitigation measures. To achieve the Paris climate goals and limit global warming to manageable levels, large investments are needed in a low-carbon transformation of infrastructure and energy systems. Moreover, economies need to invest in resilience to address vulnerabilities from extreme weather events and the effects of gradual global warming. The Global Commission on the Economy and Climate (2019) estimated that globally, until 2030, it will be necessary to spend around $\$ 90$ trillion on infrastructure, including energy, all of which needs to be sustainable and climate resilient. While parts of these investments will have to be financed by the private sector, governments will have to play an important role not only in setting the right incentives through climate policies, but also through direct fiscal spending.

A related concern is that structural shifts throughout the low-carbon transition can disrupt traditional sources of government revenue. Tax revenues from oil and gas production, as well as fuel duties can be a significant source of government revenue. For instance, in 2018, the UK Treasury received about 61.3 per cent of the price charged for each litre of pump fuel sold to consumers; the averages for the G7 and OECD are 50 and 49 per cent, respectively (OPEC, 2019). Losing such revenues due to the phaseout of fossil fuels can add significant pressure to public finances. But for some sovereigns, the risk is more acute. Jaffe (2020) points out that by far the largest holders of fossil fuel assets are state-owned enterprises. Whilst private oil majors have already begun to diversify their portfolios, the risk that sovereign holdings of fossil fuel reserves may become stranded assets is even more directly linked to sovereign creditworthiness.

\subsection{Climate-driven aggregate supply and demand shocks and impacts on output}

Both the physical and transition impacts of climate change can cause aggregate supply and demand shocks, with significant implications for output, employment and public finances. The supply- and demand-side effects of gradual global warming and transition impacts can cause fundamental and enduring structural changes to the economy (Semieniuk et al., 2021). Such impacts can be anticipated across sectors and industries. Both the supply and demand for particular types and locations of housing,

\footnotetext{
${ }^{2}$ Bova et al. (2019) analysis of contingent liability realizations in a sample of 80 advanced and emerging economies for the period 1990-2014 showed that natural disasters (including geophysical events) are one of the most important sources of contingent liabilities, the realisation of which can be a substantial source of fiscal distress.
} 
insurance products, agricultural output, transport infrastructure and even university degrees and training programmes are likely to be affected (Hepburn et al., 2020).

Current models vary in their projections of the reduction in national output (GDP) arising from different warming scenarios. Conservative estimates project reductions in global per capita GDP of between 7 and 13 per cent, varying significantly across countries depending on the pace of temperature increases and variability of climate conditions, by 2100 (Kahn et al., 2021), mid-range estimates indicate a 7-14 per cent reduction for a 3.5C warming world (Kalkuhl and Wenz, 2020), whilst estimates at the higher range indicate a loss of 21 per cent (Burke, Hsiang, and Miguel, 2015). A country's long-term growth potential will inevitably have ramifications for its public finances and debt sustainability. These could be even larger if, as recent research suggests, the volatility of temperature rises with its average (Kahn et al., 2021). Kotz et al. (2021) show that independent of the rise in average temperature, an increase in the variability of temperature by $1^{\circ}$ results in a 5 percentage point reduction in regional growth rates, on average.

\subsection{Impacts on innovation, competitiveness and efficiency}

Most accounts of the effect of climate policies on innovation take an optimistic tone. From Hicks (1932) to Stern (2007), it is argued for instance that carbon prices will induce innovation in low carbon alternatives. However, this presupposes that carbon prices are sufficient to overcome not only the emissions externality, but also any additional market failures (e.g. asymmetric market power, lobbying influence and path dependencies) that tend to favour the status quo. Moreover, if climate-induced innovation takes the form of more efficient complements for carbon intensive industries, such as a more fuel-efficient internal combustion engine, they could serve to further lock-in carbon intensive infrastructure and production. If in contrast, climate-induced innovation accelerates the adoption substitutes such as electric vehicles, the transition may be faster.

Even if the net effect of climate on innovation is positive, genuine concerns about how this translates into fiscal risk remain. For instance, if climate-driven innovations render human and physical capital obsolete, the employment and subsequent social effects could be severe (see Section 2.9). Assets that were initially expected to be productive for many years may become stranded abruptly. In order to meet climate targets consistent with a 50/50 chance of limiting temperatures to $2^{\circ}$ above pre-industrial times, a third of global oil reserves, half of gas reserves and 80 per cent of current coal reserves will have to remain in the ground or, if they are burned, the emissions will have to be captured and stored (McGlade and Ekins, 2015). But the risk from stranding does not end with fossil fuels. 'Downstream' transport infrastructure, refineries, carbon-intensive industrial facilities and power generation assets also risk being stranded. Financial services heavily invested in all these fossil fuel entangled sectors will also be hit with great concerns around systemic risk and sovereign risk, if large financial institutions or governments become insolvent (Pfeiffer et al., 2016). Skills, ideas and institutions will also become outmoded.

Another concern is the global distribution of innovation and its rewards. Countries which delay investment and transition could miss out on first-mover advantages, learning by doing and global competitiveness (see Section 6). Finally, the possibility cannot be ruled out that delayed action means that climate change imposes significant physical losses on national output, unevenly distributed across countries. In such a world, it is reasonable to consider that innovation and competitiveness in the hardest hit countries would suffer significantly.

\subsection{Effects of climate change on productivity}

The direct and transition effects of climate change on productivity are likely to be negative on net, owing largely to its effects on human, physical and natural capital. The likely effects of warming, and especially rising temperature volatility, on human health and labour productivity are increasingly well established 
and their consequences for national output are of first order concern (Day et al., 2019). Despite difficulties in distinguishing between supply and productivity effects, empirical studies and model results generally agree that the effect of climate on labour will vary across sectors (indoor vs. outdoor work; see Kahn et al., 2021 for a within-country study of the ten sectors in the United States) and countries (it will be more severe in the tropics) (Dasgupta et al., 2021). Estimates indicate that heat stress has already reduced labour capacity by 10 per cent in peak temperature months over recent decades, and could rise to a 20 per cent reduction in labour capacity globally in the hottest months by 2050 (Dunne et al., 2013).

The productivity effects are of course not limited to impacts on human capital. Recent years have seen physical infrastructure forced to operate at reduced capacity due to extreme weather events. Obvious examples for the UK include trains operating at reduced speeds due to high temperatures (which affect metal tracks), airport disruption due to winter storms and local transport disruptions due to floods. In Texas, winter storm Uri in February 2021 triggered a wave of blackouts as energy infrastructure seized in sub-zero temperatures, leaving more than two-thirds of Texans without power for an average of $42 \mathrm{~h}$ during the week of the storm, and an official death $\operatorname{toll}^{3}$ of 151 (Watson et al., 2021). Both the impairment and stranding of physical infrastructure have consequences for productivity estimates and subsequently, macroeconomic risks.

\subsection{Climate risks to financial system stability}

Climate change, and policy responses to it, pose a material and systemic risk for the financial sector (Bolton et al., 2020; Monasterolo, 2020; NGFS, 2019). Using an IAM to estimate the expected 'climate value at risk' (climate VaR) of global financial assets, Dietz et al. (2016) show that 1.8 per cent of total global financial assets were at risk of climate change along a business-as-usual emissions path, and because risks are concentrated in the tails, this rises to 16.9 per cent for the 99th percentile of climate VaR. This has direct consequences for pensions and investment funds, especially given their heavy exposure to assets that could become stranded in a disorderly transition to net zero (Battiston et al., 2017).

Such climate-induced financial vulnerabilities can spill over to the public sector and give way to a negative feedback loop between financial sector instability and sovereign risk (Acharya et al., 2014; Angelini et al., 2014; Dell'Ariccia et al., 2018; Farhi and Tirole, 2018; Gennaioli et al., 2018). A weakening of the sovereign balance sheet due to public debt-funded bailouts of banks can further weaken the credit profile of banks due to their sovereign debt holdings and lead to a 'doom loop' (Farhi and Tirole, 2018). Governments may also rely on domestic banks as a source of funding during periods of financial crisis, putting additional pressure on them to hold more government bonds and worsening the negative feedback effects between financial sector and sovereign risk.

\subsection{Impacts on international trade and capital flows}

Climate change can have substantial impacts on an economy's trade in goods and services and capital flows with the rest of the world with potentially significant ramifications for countries' balance of payments positions and, ultimately, sovereign risk. Both the physical impacts of climate change and the disruptions resulting from the climate policies that trading partners adopt, technological change or changes to consumption patterns can affect international trade and financial flows. Historically, balance of payment problems have often been at the root of country risk and led to external debt crises (Bouchet et al., 2018). Protracted current account imbalances tend to cause liquidity problems and, if not resolved, solvency problems. The current account balance is therefore an important indicator of sovereign risk.

\footnotetext{
${ }^{3}$ Further analysis based on excess death calculations put the death toll between 426 and 978 , with a best estimate of 702 (Aldhous et al., 2021).
} 
Decarbonising the global economy may have counterintuitive consequences for many fossil fuel-rich nations. Ultimately, the magnitude and even the sign of the effect on fossil fuel export revenues depends on the characteristics of resource endowments, including carbon intensity and ease of extraction. Some models suggest that oil and gas owners may benefit during the transition if carbon taxes make dirtier fuels, such as coal and heavy oil less competitive (Coulomb and Henriet, 2018). Whilst the most carbonintensive fossil fuels will likely be stranded, some estimates suggest the so-called 'Grey Paradox' could increase the net present value of OPEC revenue by up to 4 per cent (Persson et al., 2007).

\subsection{Impacts of climate change on political stability}

The economic and social effects of climate change may accentuate the social tensions within a society and fuel political instability. Moreover, climate change leads to large-scale migration movements, which could also lead to political tensions or even inter- and intrastate conflicts. Political instability can undermine the ability or willingness of a government to repay its debt. For instance, Clark (1997) emphasised the potential impact of political events on the probability of sovereign default, while Cuadra and Sapriza (2008) maintained that countries that are politically unstable and more polarised have higher default rates and as a result have to pay a higher default risk premium in international credit markets.

These transmission channels are not independent of each other. Climate impacts can magnify the transmission of risk through multiple channels. The socioeconomic and fiscal effects of climate change are multifaceted and depend on the policies taken or not to mitigate and adapt to these risks. Nor is it guaranteed that all of the impacts through these transmission channels will necessarily be negative, that is, exacerbating risk. Particularly around issues of innovation, competitiveness and productivity, welldesigned climate policies can actually serve to reduce sovereign risk. This is especially likely if mitigation and adaptation policies enhance human, physical and natural capital (Agarwala et al., 2020). Similarly, a revolution in green finance could help support a just transition characterised by high returns as low-carbon investments and technologies begin to out-compete their carbon-intensive counterparts. Climate-proofing public finances hence ought to be a key priority of public policy.

\section{Climate risks and sovereign creditworthiness}

Despite growing evidence of the risk channels outlined in Section 2, mainstream estimates of sovereign risk-especially sovereign credit ratings-have so far been slow to adjust. Although credit ratings agencies have started to discuss climate-related risks, even acquiring climate data firms, there is little evidence that sovereign ratings have been affected. This is an important consideration. The efficient market hypothesis depends on the availability of reliable information about risk. If sovereign ratings cannot be shown to respond to the growing scientific and economic evidence of the consequences of climate change, markets and investors may struggle to correctly identify, price and manage risk throughout their portfolios.

Recent empirical analyses suggest that the scientific and economic evidence is sufficient to demonstrate an effect of climate on sovereign creditworthiness. By introducing an integrated assessment model into the European Stability Mechanism's debt sustainability analysis optimisation model, Zenios (2021) finds that adverse climate effects on debt dynamics arise as early as 2030. He argues that European institutions including the European Commission, European Central Bank, European Stability Mechanism, European Fiscal Board and member states' finance ministries should incorporate climate change into sovereign risk assessments.

Cevik and Jalles (2020a) estimate the effect of climate vulnerability on credit ratings of 67 sovereigns between 1995 and 2017, finding that vulnerability negatively affects sovereign credit ratings. However, the result is not robust to different model specifications. More fundammentally, this backwards-looking analysis cannot be used to make inferences about the future affect of climate change on creditworthiness, 
Panel A: Climate-adjusted Ratings: 2030-2100 (RCP 8.5)

Panel B: Climate-adjusted Ratings: 2030-2100 (RCP 2.6)
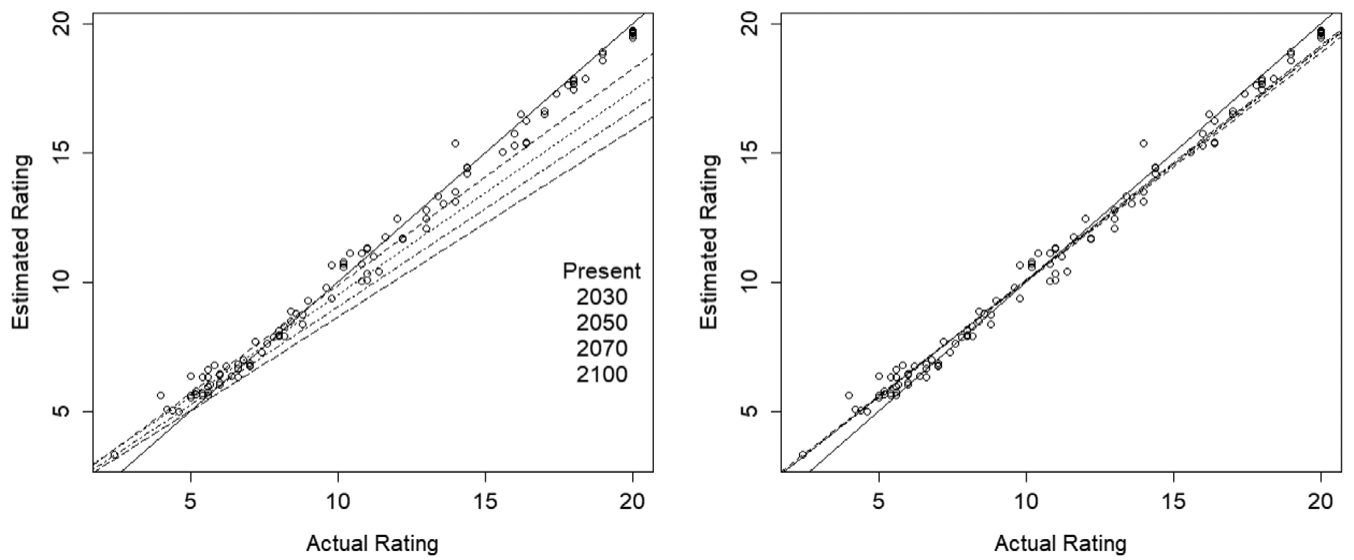

Figure 2. Climate-adjusted ratings to 2100 (RCP 8.5 vs. 2.6). Source: Klusak et al. (2021). The horizontal axis indicates current ratings by S\&P and the thick black line represents exact matches between current and predicted ratings. The dotted lines are the best fit lines for climate-adjusted ratings under RCP 8.5 and 2.6, respectively, for 2030, 2050, 2070 and 2100 (Panels A and B). RCP 2.6 and RCP 8.5 are consistent with warming of less than $2 \mathrm{C}$ and $4.5-5 \mathrm{C}$ relative to pre-industrial levels, respectively.

which is clearly the more important question for managing the public finances over the medium- to longrun.

Klusak et al. (2021) is the first paper which offers a forward-look into the effects of climate on sovereign credit ratings. Combining climate-economic models with observed sovereign ratings and an artificial intelligence (AI) model, they construct the world's first climate adjusted sovereign rating for 108 sovereigns under three climate scenarios. Results indicate that climate change will exert downward pressure on ratings as early as 2030 with an increasing magnitude throughout the century (see Figure 2). Preliminary results show that if global emissions follow their recent trend, the UK could see a 1-notch downgrade (on a 20-notch rating scale) by 2030, growing to more than three notches by the end of century under a high emissions scenario (RCP 8.5). If instead emissions profiles are consistent with limiting warming to $2 \mathrm{C}$, the UK's sovereign downgrade would be limited to approximately 1 notch by 2100 .

\section{Climate change and the cost of sovereign debt}

Weak fiscal positions characterised by high debt, high deficits and low growth increase sovereign the cost of public borrowing (Barrell and Holland, 2009). Whilst early climate models indicated that the worst effect of climate change would accrue far in the future, sovereign debt markets may be expected to price these effects in earlier. Indeed, empirical evidence suggests that climate vulnerability has already raised the average cost of debt in climate-vulnerable developing countries. A first analysis of the nexus between climate vulnerability and the cost of capital by Kling et al. (2018) showed that countries with higher exposure to climate vulnerability incur a risk premium on their sovereign debt. $^{4}$ Conducting a panel and principal component analysis with annual data for a sample of developing and advanced 46 countries over the period 1996-2016, Kling et al. (2018) find that, controlling for macroeconomic factors, climate vulnerability has increased debt costs for a subgroup of 25 climate-vulnerable developing countries by

\footnotetext{
${ }^{4}$ Kling et al. (2021) show that this effect also extends to the corporate cost of capital. Using panel data of 15,265 firms in 71 countries over the period 1999-2017, they invoke panel data regressions and structural equation models and show that climate vulnerability increases the cost of corporate debt directly and indirectly through its impact on restricting access to finance.
} 
1.17 percentage points. In absolute terms, this translates into $\$ 40$ billion in additional interest payments for 40 climate-vulnerable countries over the period 2007-2016 on government debt alone. Projections suggest additional interest payments attributable to climate vulnerability to increase to between $\$ 146$ and 168 billion for the same group of countries over the next decade (Buhr et al., 2018).

Subsequent studies have corroborated the positive effect of physical climate vulnerability on the cost of government debt. Using data for 98 advanced and developing countries over the period 19952017, Cevik and Jalles (2020b) replicate the methodology and measures employed by Kling et al. (2018) and confirm their findings. Using refined measures of climate risk and resilience and a higher data frequency for 40 advanced and emerging economies, Beirne et al. (2021a) also confirm the findings of a climate risk premium by Kling et al. (2018). Moreover, Beirne et al. (2021a) develop a set of panel structural VAR models that indicate the reaction of bond yields to climate risk shocks becomes permanent after around 18 quarters with high-risk economies experiencing the largest permanent effects on yields. Beirne et al. (2021b) conduct an in-depth analysis of the link between climate change and sovereign risk in Southeast Asia, one of the regions most heavily affected by climate change. Both the country-specific and the panel estimates for six Southeast Asian countries with monthly data for the period 2002-2018 show that greater climate vulnerability appears to have a sizable positive effect on sovereign bond yields, while greater resilience to climate change has an offsetting effect, albeit to a lesser extent.

Looking at climate transition risk, Battiston and Monasterolo (2020) employ a financial pricing model with forward-looking simulations to estimate effects of climate risk on the sovereign bond yields of 34 countries. They find that economies that are highly exposed to carbon-intensive sectors incur higher yields on their sovereign bonds. Klusak et al. (2021) use an AI-based approach to estimate the additional cost of sovereign and corporate debt resulting from climate-driven downgrades under various warming scenarios. Under the low emissions scenario (RCP 2.6) the UK's 0.92-notch downgrade by 2100 would amount to an increase in the annual interest payment on public debt of \$2.0-3.0 billion and an increase of \$250-440 million on corporate debt. Under the high emissions scenario (RCP 8.5), this rises to $\$ 7.54-11.31$ billion and $\$ 0.94-1.65$ billion in additional interest payments on sovereign and corporate debt respectively. Relative to 2020-2021 levels, the increase in annual debt servicing costs for UK central government debt (net of the Asset Purchase Facility) ranges from 9 to 13.6 per cent under RCP 2.6-33.850.7 per cent under RCP 8.5 (House of Commons, 2021). These preliminary estimates should be considered severe underestimates because the effect of downgrades is placed on the pre-pandemic level of debt. The figures would grow with the level of debt over the century.

For comparison, figures for G7 plus China show that climate-induced downgrades could increase the cost of sovereign debt by $\$ 18.18-27.27$ billion (\$113.93-170.89 billion) under the RCP 2.6 (RCP 8.5) scenario. The additional annual interest payments of corporations will reach $\$ 5.35-9.36$ billion (20.7536.31 billion) by 2100 .

\section{Measuring the impact of a transition to net zero on the UK economy and public finances: Using OBR and CCC projections}

In this section, we demonstrate how the transmission pathways set out in Section 2 map onto the likely impacts of the UK's transition to net zero on the national economy and the public finances, drawing insights from the UK OBR's recent Fiscal Risks Report (OBR, 2021). The report uses the highly credible UK Climate Change Committee (CCC) figures to conclude that meeting net zero will leave GDP 1.4 per cent lower than the hypothetical counterfactual path in 2050 and public debt 21 per cent of GDP higher. It is important to note that the report makes no attempt to account for the positive impact on UK debt from forgone climate damages and risks, reflecting the fact that the UK is a marginal player when it comes to global emissions. The focus is therefore solely on transition costs from the UK's efforts to reduce emissions and efforts to adapt to a changing climate and associated risks. Nevertheless, the headline analysis needs to be interpreted carefully and masks a much richer story. 
Firstly, the likely costs and benefits are unevenly distributed through time. Higher net spending outlays early on are likely to generate higher net revenues down the line, thereby promoting rather than eroding public debt sustainability over the longer term.

Early fiscal outlays must be viewed as investment costs, which expand the public sector's net worth by generating net revenues or public returns down the line. Indeed, the CCC numbers which the OBR uses show that by 2050, operating costs in most sectors are expected to be lower than under a net zero scenario relative to baseline, a trend that would be expected to continue through the second half of the century with the potential to boost the public finances. Starting with cars, and moving progressively sector by sector, the falls in operating costs become so large that in total they begin to offset the additional capex costs (see Figure 3) from around 2040 net 'costs' become negative.

By truncating the cost benefit analysis at 2050, and assessing the integral only over the next 30 years, the OBR analysis includes the bulk of the (front-loaded) investment cost, but excludes decades and centuries of future net gains. To illustrate the point, consider a policymaker charged with assessing the case for education spending. The cost savings over this period from eliminating public spending on primary, secondary and tertiary education might well exceed the forgone net revenues from lower wages and social disruption in the first 30 years. Yet, a policymaker would be rash to scrap all education spending knowing that a stream of positive net returns will accrue for many decades into the future, just because they fell outside the analytically arbitrary cut-off date for the projection.

The second question surrounds the presumed impact of early action on productivity growth. The baseline numbers assume that additional investment to address climate impacts and transition requirements crowds out alternative investment and leaves UK productivity lower by mid-century. But this is far from a foregone conclusion. An accurate prediction of the impact of a low-carbon transition on GDP in

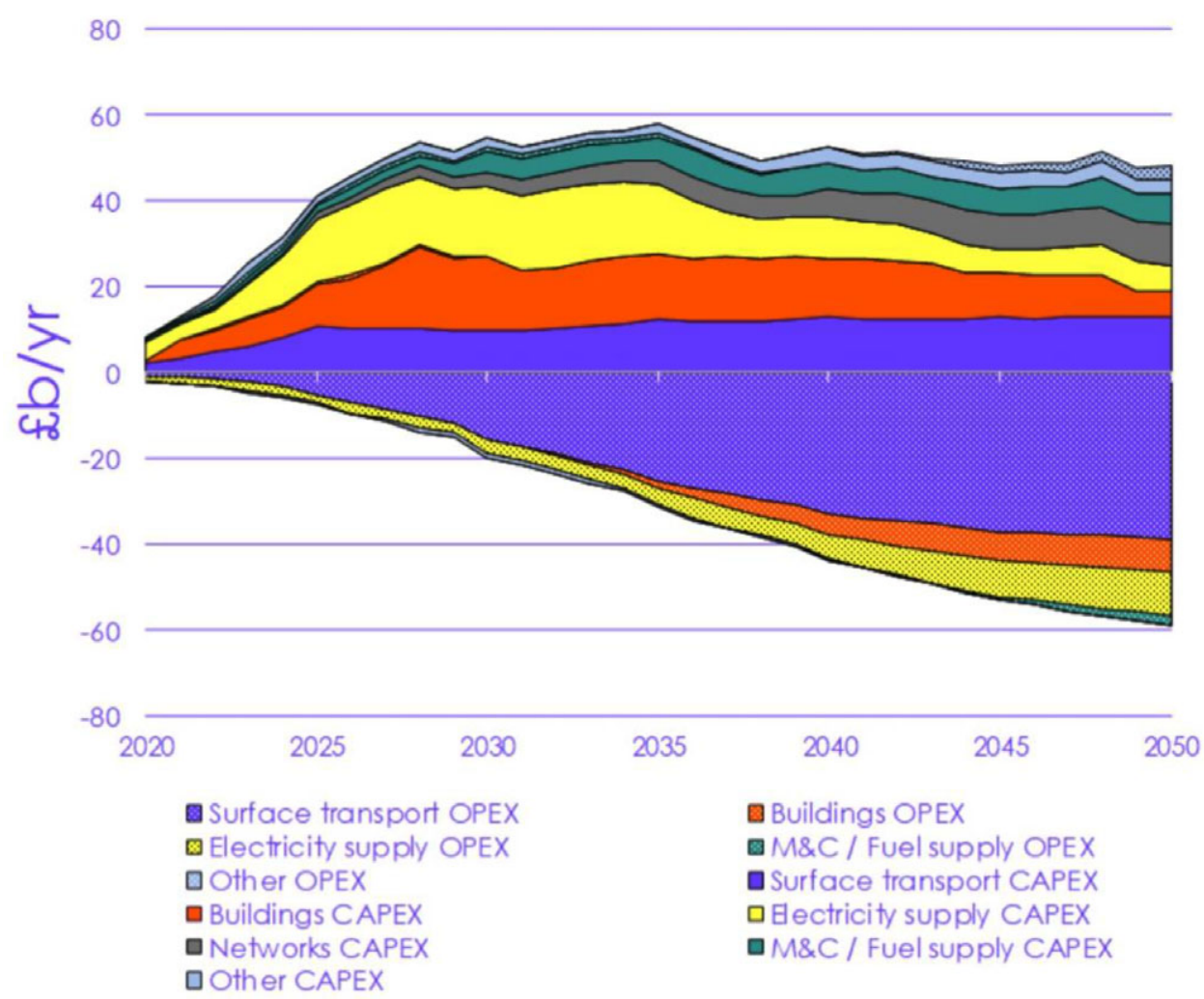

Figure 3. (Colour online) Capital and investment costs and operating cost savings in the Balanced Net Zero Pathway. Source: UK Climate Change Committee (CCC), Sixth Carbon Budget (2021). 
30 years' time is, of course, unrealistic. But it is important to note that the numbers quoted by the OBR are hugely sensitive to changes in the economy's dynamic productive potential. The OBR's own calculations suggest a boost to annual productivity growth of less than 0.05 per cent would potentially wipe this out this loss. ${ }^{5}$

Such a productivity gain is not trivial, were it available. But it is important to recognise that this is not an absolute gain, it is a hypothetical gain assessed against a baseline scenario in which the UK charts a future based on high-carbon goods and services. However, such a scenario is highly vulnerable to negative output shocks associated with stranded and devalued assets. All told, there is evidence to suggest that the OBR are being overly conservative. Over time, investing in cleaner, more efficient and innovative production is likely to be more productive than relying on the technologies of the previous century (Way et al., 2021). This is even before account is taken of climate damages, which can mount much more quickly as productivity growth is eroded through endogenous impact of destroyed or devalued capital (Dietz and Stern, 2015).

The economics of innovation and productivity means the cost of meeting various decarbonisation and resource-management targets are not only hard to predict, but that they are path-dependent (Aghion et al., 2014). Initial conditions and decisions made today, in changing behaviour and generating innovation, matter greatly. Relatively small interventions can generate a virtuous cycle of innovation, investment and falling costs of green technologies as evidenced in the renewable energy and vehicle sectors. By contrast, lock-in of resource- and carbon-intensive infrastructure, behaviour and institutions increases the cost of attaining sustainable pathways.

The sheer scale of the low-carbon transition generates productivity enhancing network effects and economies of scale in production and discovery. These are already apparent having caught most commentators by surprise. The price of solar photovoltaic has dropped by 83 per cent since 2010 , a period over which the price of wind turbines fell nearly 40 per cent (Liebreich, 2018). These technologies are increasingly producing cheaper power than most coal- and many gas-fired power plants (Figure 4).
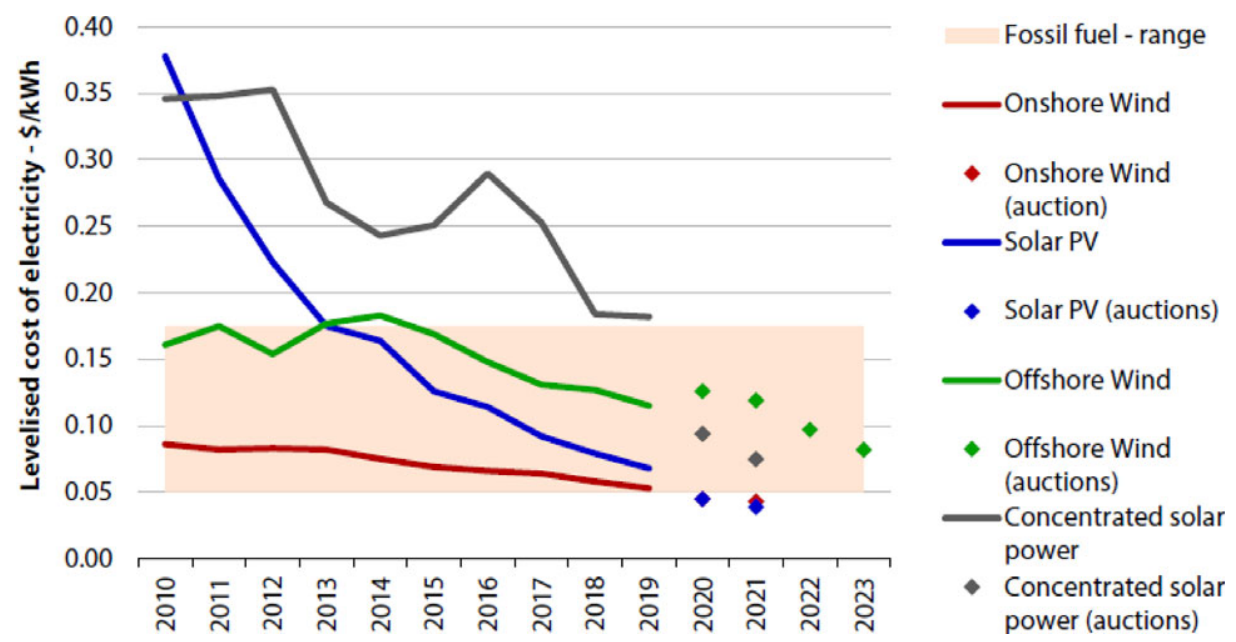

Figure 4. (Colour online) Levelised costs of electricity (constant 2019 US dollars per kWh). Source: Committee on Climate Change, 2020.

\footnotetext{
${ }^{5}$ See Section 3.127 of the OBR's, 2021 Fiscal Risks Report. It should also be noted that the compositional affects from the transition on net revenues (e.g. losses in vehicle excise duty revenues) can be compensated by changes in tax rates and regimes. But the impact on the public finances from changes in the underlying growth of consumption, wages, profits and employment are harder to offset without adding distortions to the economy.
} 
The important lesson from Figure 4 is not just that renewable energy now competes with fossil fuels (net of infrastructure and subsidies), but rather how this transition came about and what lessons can be learned to stimulate further innovations. The pace and extent of cost reductions required a series of several interconnected, amplifying feedback mechanisms. These include:

- Learning-by-doing. With deployment, lessons are learned on how to manufacture, distribute, install, run and maintain equipment more efficiently.

- Economies of scale in production and distribution. Unit cost fall as production and distribution ramp up once large, fixed costs are incurred.

- Network and coordination effects. This reflects the greater advantages of moving in tandem with others, such that the gains are higher the more economic agents are taking similar action.

- Sector spill-overs. Not only have sustainable technologies been shown to have predictably higher cost-reducing learning rates, but they have also been shown to have positive productivity spillovers into other sectors of the economy. Using data on 1 million patents and 3 million citations, Dechezleprêtre et al. (2014) suggest that productivity enhancing spill-overs from low-carbon innovation are over 40 per cent greater than from conventional technologies (in the fossil fuel energy production and transportation sectors).

- Social and institutional feedbacks. Acceptable standards of behaviour and social norms are liable to change (Licht, 2008; Ostrom, 2000; Posner, 1997).

- Evolution of consumer behaviour. Consumer tastes are key in the attribution of future value to goods and services and consumers routinely influence one another, leading to positive feedbacks and crowd effects and changing consumption patterns. The heterogeneity of real-world consumer behaviour is readily inferred from standard innovation diffusion theory where technology adoption typically follows s-shaped patterns starting with innovators and early adopters, through the majority to finally affect laggards (Mercure et al., 2021)

- Expectations. People's changing expectations with shape the nature and pace of change. Perception of new technologies as superior leads to behaviour change which itself facilitates their successful adoption (Van der Meijden and Smulders, 2017). Expectations that the cost of a net zero transition will be inevitable and affordable can become self-fulfilling (Zenghelis, 2021a).

Figure 5 demonstrates how these economic phenomena interact to drive innovation and transition. Note that initially, low levels of installed capacity are associated with high costs. This means markets alone were highly unlikely to deliver the necessary transition. Early-on, government leadership (subsidies and signals) was needed to drive initial investments. Learning-by-doing and economies of scale drove efficiency gains as installed capacity grew. Notably, coal has not become significantly cheaper over the same time period. Instead, social norms and consumer behaviour have driven demand for renewable energy, and in many parts of the world, for the complementary purchases such as electric vehicles. Strong policy signals on the phase-out of internal combustion engines have further shaped expectations, and manufacturers are responding by increasing the range of EVs available on the market.

Whilst it remains to be seen whether the story of renewable energy is an exception-the timescales, cost profiles and innovation pathways in other sectors may differ-it is clear that an early start, corresponding to the OBR net zero scenario, is therefore likely to cut the costs of transition and improve economic performance compared with delay and indecision. It may also be pivotal to shaping the longterm sustainability of the public finances.

The potential net benefits from early action would be expected to be higher if the UK moves in tandem with the other countries in imposing ambitious policies to generate innovation at scale. In such an environment, the net gains from low carbon investments would be far higher and the estimated increase in borrowing costs and corresponding downgrades in sovereign ratings reported in Sections 3 and 4 would also be far smaller, testifying to the importance of global coordination. Although Klusak et al. (2021) identify the possibility of climate-driven downgrades even under RCP 2.6, their model makes no 


\section{Electricity from renewables became cheaper as we increased Our World capacity - electricity from nuclear and coal did not

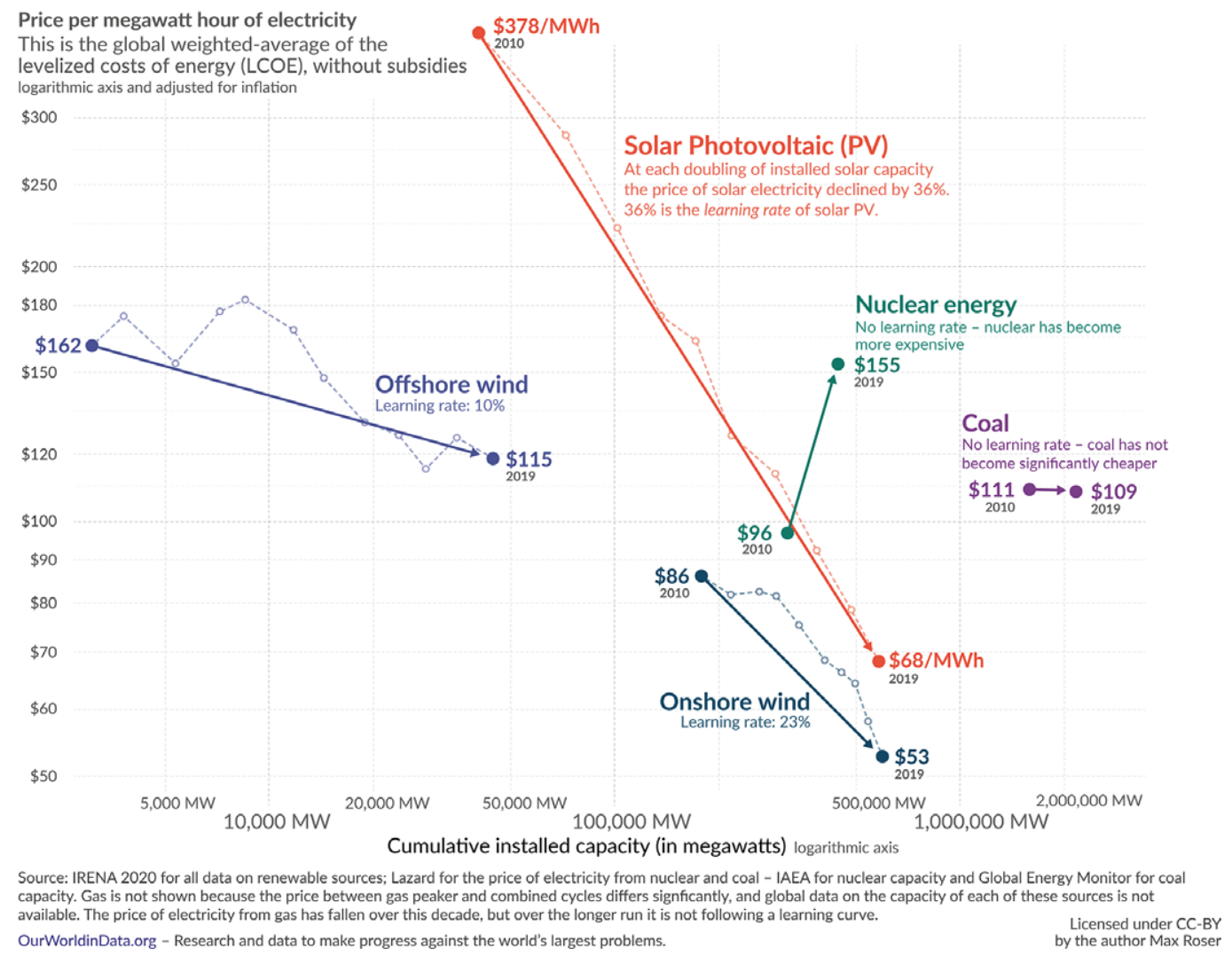

Figure 5. (Colour online) Renewable electricity costs fall as installed capacity rises. Source: Our World in Data (2021).

adjustment for early investments in adaptation. As the treatment of climate change in sovereign ratings methods becomes more sophisticated, one would expect investments in adaptive capacity to reduce the downward pressure of climate on ratings.

\section{Competitive position and macroeconomic context}

The transition will also affect any advanced economy's competitive position in changing world markets. Most European countries are small to medium sized open economies. Productivity and growth over long time periods will be driven by comparative as well as absolute advantages in new markets and these are not set in stone but are shaped by policy. This goes beyond comparing absolute investment and operating costs.

Falling behind on policies and investments may induce significant displacement of high productivity (and high productivity growth) activities to other countries, if the world shifts to low carbon resource efficient markets (e.g. as a result of global policies hostile to high carbon activities and undercutting technologies outcompeting high carbon incumbents).

Hidalgo et al. (2007) and Mealy and Teytelboym (2021) use network analysis to demonstrate that it is easier for countries to become competitive in new green products that require similar production capabilities and know-how to existing sectors. This helps demonstrate how green transitions are highly path-dependent: countries which successfully invest early in green capabilities have greater success in 
diversifying into future green product markets. This also has potential implications for industrial policy seeking to develop comparative advantages in fast growing new sectors. The potential fiscal risks should be clear.

Other studies focus on 'revealed technological advantage' to determine where opportunities for sustainable growth and recovery might reside. Martin et al. (2020) compare broad categories of technologies and find that the UK is relatively specialised in wind and ocean energy, as well as biotechnology and pharmaceuticals. They argue that the returns to public investments in these technologies are likely to be disproportionately high, improving the UK's longstanding poor productivity performance and competitiveness while also addressing large-scale disparities across and within regions (see also Stern and Valero, 2021).

The impact of adopting policies to transition the economy to net zero, and associated risks, is a function of the broader global macroeconomic context. Recent evidence on productivity strongly suggests the world needs markedly higher investment (Zenghelis, 2021b). Weak private confidence has meant ex ante desired investment lagged desired saving for more than a decade, driving real risk-free interests rates to below zero. ${ }^{6}$

Negative rates in turn push the efficacy of monetary policy to its limits, fuelling asset price rises that disproportionately benefited the rich. A fundamental policy error following the crash of 2008 was introducing austerity programmes to balance budgets prematurely. Reduced public borrowing to invest exacerbated the problem of excess net saving (Auerbach and Gorodnichenko, 2017). Research suggests European countries suffered a decade of lower growth than the United States, which adopted a far more relaxed fiscal stance (Jordà and Taylor, 2016).

\section{Conclusion and policy imperatives}

Climate change poses new risks which will affect the financial system, fiscal sustainability and sovereign debt markets. At the same time, attempts to meet agreed climate targets will require an unprecedented structural transformation of the global economy over the next two or three decades. The changing landscape of risks warrants new risk management and hedging strategies to contain climate risk and minimise the impact of asset stranding and asset devaluation. Yet, conditional on action being taken early, the opportunities from managing a net zero transition would substantially outweigh the costs.

Public investment in complimentary assets alongside supportive policies and institutions are prerequisites to 'crowd in' sustainable capacity and bolster the structural resilience of the economy. This historic growth opportunity has been reflected in large stimulus and recovery packages adopted in the Europe, the United States and other advanced economies. Each has placed clean investment at its heart.

Yet the call for public investment to boost productive capacity, following an unprecedented government response to the global pandemic, understandably has raised concerns about fiscal space. Public debt relative to GDP is already close to historic highs in many European countries. Combined with record broad money supply growth it has also rekindled fears of the return of inflation (Haldane, 2021).

These justifiable fears notwithstanding, the risks from higher public debt in the short term, are far lower than the likely benefits (Stern and Zenghelis, 2021). There are increasing opportunities associated with a public drive to steer a zero-carbon economy which can crowd in investment and expand capacity. The IMF Fiscal Monitor for October 2020 argued that an additional $£ 1$ in public borrowing to invest in 'job-rich, highly productive and greener activities' would generate an additional $£ 2.7$ of additional output (IMF, 2020; Gaspar et al., 2020). This marks scope for strong crowding-in. The markets agree: they continue to lend to

\footnotetext{
${ }^{6}$ The term neutral refers here to the rate that would prevail when the economy is operating close to capacity, not requiring either a tight/loose monetary stance to contain/stimulate demand. It reflects underlying structural factors shaping preferences for desired savings and investment, rather than cyclical positions dictated by policy rates. It reflects a countries equilibrium real rate of interest in the long run. According to Rachel and Smith (2015), lower expectations for trend growth and shifts in desired savings and investment have driven a 400 bps of the 450 bps decline in the global long-term neutral rate since the 1980 s. See Stern and Zenghelis (2021).
} 
governments at real interest rates which remain at near-record lows. The most promising way to bring down public debt in the medium term is to borrow to invest now (Chudik et al., 2017).

A fundamental feature of transition and climate change is that the infrastructure, skills and ideas of the last century can quickly become a liability. Resource- and carbon-intensive physical, human and knowledge assets risk becoming devalued or obsolete. Early indications suggest that this may already be affecting some asset prices, even as fossil fuels continue to play a key role in the economy. However, due to the difficulty of translating climate risks to financial risks, markets have been slow to respond. It is for this reason that the Financial Stability Board's Task Force for Climate Related Disclosure is calling for mandatory disclosure and stress testing of assets (TCFD, 2017).

It is increasingly recognised that growth is not only compatible with sustainability, but also requires it (Zenghelis, 2021b). Recent studies have highlighted the urgent need to strengthen the quality of natural assets (New Climate Economy, 2018). They also point to numerous near-term opportunities associated with tackling particulate pollution, congestion, ill-health, biodiversity loss, inefficiency and waste and building more attractive, liveable cities. This is especially true after the COVID pandemic, which marks a period of dislocation and change affording a potential opportunity to lock in to pathways which create durable and resilient jobs (Stern et al., 2020).

A recent survey of 231 economic experts from G20 countries, including central bank and finance ministry officials, found that major fiscal recovery packages that focussed on clean R\&D spending, clean energy infrastructure, connectivity infrastructure, building upgrades, energy efficiency and investment in green spaces were considered best placed to boost long term growth (Hepburn et al., 2020).

\subsection{Just and inclusive policies will lower transition costs}

With many of the key barriers to the low-carbon transition being political and behavioural, rather than technological and economic, policymakers recognise the need to act quickly and carefully to ensure that change is in the interest of the many. This means compensating, reskilling and retooling those who stand to lose out, enabling them to participate in the new economy and provide the jobs of the 21 st century. It also means supporting overstretched consumers who may face higher charges to fund transitional infrastructure investment. Ensuring a just transition will be central to maintaining social cohesion (Robins et al., 2019; Rydge et al., 2018).

So how big are transition risks? The correct answer is that it is 'endogenous' (Ekins and Zenghelis, 2021). It depends on the choices and actions we take today and in the future. The longer we wait to manage that transition, the bigger the dislocation risks and the higher the adjustment costs. Understanding the processes which drive innovation, change social norms and build stronger institutions will help decision-makers steer growth in a manner that is not only cleaner and more secure, but also more innovative, competitive and productive. This reduces transition risk. By this logic, any optimism must be conditional. It requires credible and ambitious action in the near term to avoid catastrophic and irreversible environmental risk and unleash private ingenuity and finance to build a more efficient, innovative and productive economy.

Acknowledgements. The authors are grateful Yamini Cinamon Nair for excellent research assistance and to Moritz Kramer, Stavros Zenios, NIESR and the organisers and participants of the $17^{\text {th }}$ EUROFRAME Conference for insightful comments. We also thank the Editorial team and anonymous referees for helpful suggestions. MA, MB and PK acknowledge funding from the INSPIRE Network, MA \& DZ acknowledge funding from the Wealth Economy project supported by LetterOne and The Productivity Institute, funded by the UK Economic and Social Research Council (grant number ES/V002740/1).

\section{References}

Acevedo, S. (2014), 'Debt, growth and natural disasters: A Caribbean trilogy', IMF Working Paper 14/125, International Monetary Fund, Washington, DC.

Acharya, V.V., Drechsler, I. and Schnabl, P. (2014), 'A pyrrhic victory? Bank bailouts and sovereign credit risk', Journal of Finance, 69, 6, pp. 2689-739. 
Agarwala, M., Cinamon Nair, Y., Cordonier Segger, M.C., Coyle, D., Felici, M., Goodair, B., Leam, R., Lu, S., Manley, A., Wdowin, J. and Zenghelis, D. (2020), 'Building forward: Investing in a resilient recovery', Wealth Economy Report to LetterOne. Cambridge: Bennett Institute for Public Policy, University of Cambridge.

Agarwala, M. and Coyle, D. (2020), 'Natural capital in climate models', Nature Sustainability, 4, pp. 81-2.

Aghion, P., Hepburn, C., Teytelboym, A. and Zenghelis, D. (2014), 'Path dependence, innovation and the economics of climate change', Centre for Climate Change', Economics and Policy/Grantham Research Institute on Climate Change and the Environment Policy Paper \& Contributing Paper to New Climate Economy.

Aldhous, P., Hirji, Z. and Lee, S.M. (2021), 'The Texas winter storm and power outages killed hundreds more people than the state says', BuzzFeed News, May 26. Available at https://www.buzzfeednews.com/article/peteraldhous/texas-winter-stormpower-outage-death-toll [Accessed 31 August 2021].

Amstad, M. and Packer, F. (2015), 'Sovereign ratings of advanced and emerging economies after the crisis', BIS Quarterly Review, pp. 77-91.

Angelini, P., Grande, G. and Panetta, F. (2014), 'The negative feedback loop between banks and sovereigns', Bank of Italy Occasional Paper 213, Bank of Italy, Rome.

Auerbach, A.J. and Gorodnichenko, Y. (2017), 'Fiscal stimulus and fiscal sustainability', NBER Working Paper 23789, National Bureau of Economic Research, Cambridge, MA.

Barrell, R. and Holland, D. (2009), 'Debts, deficits and borrowing costs', National Institute Economic Review, 208,1 , pp. $39-43$.

Bastien-Olvera, B.A., Moore, F.C. (2020), 'Use and non-use value of nature and the social cost of carbon', Nature Sustainability 4, pp. 101-8.

Battiston, S., Mandel, A., Monasterolo, I., Schütze, F. and Visentin, G. (2017), 'A climate stress-test of the financial system', Nature Climate Change, 7, pp. 283-8.

Battiston, S. and Monasterolo, I. (2020), 'A climate risk assessment of sovereign bonds', Mimeo. Zurich: University of Zurich.

Beirne, J., Renzhi, N. and Volz, U. (2021a), 'Feeling the heat: Climate risks and the cost of sovereign borrowing', International Review of Economics and Finance, 76, pp. 920-36.

Beirne, J., Renzhi, N. and Volz, U. (2021b), 'Bracing for the typhoon: Climate change and sovereign risk in Southeast Asia', Sustainable Development, 29(3), pp. 537-51.

Bolton, P., Despres, M., Awazu Pereira Da Silva, L., Samama, F. and Svartzman, R. (2020), The Green Swan: Central Banking and Financial Instability in the Age of Climate Change, Basel: Bank of International Settlements.

Botzen, W.J.W., Deschenes, O. and Sanders, M. (2019), 'The economic impacts of natural disasters: A review of models and empirical studies', Review of Environmental Economics and Policy, 13, 2, pp. 167-88.

Bouchet, M.H., Fishkin, C.A. and Goguel, A. (2018), Managing Country Risk in an Age of Globalization. A Practical Guide to Overcoming Challenges in a Complex World, London: Palgrave Macmillan.

Bova, E., Ruiz-Arranz, M., Toscani, F.G. and Elif Ture, H. (2019), 'The impact of contingent liability realizations on public finances', International Tax and Public Finance, 26, 2, pp. 381-417.

Buhr, B., Volz, U., Donovan, C., Kling, G., Lo, Y., Murinde, V. and Pullin, N. (2018), Climate Change and the Cost of Capital in Developing Countries, London and Geneva: Imperial College London, SOAS University of London and UN Environment.

Burke, M., Hsiang, S. and Miguel, E. (2015), 'Global non-linear effect of temperature on economic production', Nature, 527, pp. 235-9.

Cevik, S. and Jalles, J.T. (2020a), 'Feeling the heat: Climate shocks and credit ratings', IMF Working Paper 20/286, International Monetary Fund, Washington DC.

Cevik, S. and Jalles, J.T. (2020b). 'This changes everything: Climate shocks and sovereign bonds', IMF Working Paper 20/79, International Monetary Fund, Washington DC.

Chudik, A., Mohaddes, K., Pesaran, M.H. and Raissi, M. (2017), 'Is there a debt-threshold effect on output growth?', Review of Economics and Statistics, 99(1), pp. 135-50.

Clark, E. (1997), 'Valuing political risk', Journal of International Money and Finance, 16, pp. 477-90.

Committee on Climate Change (2020), 'Reducing UK emissions Progress Report to Parliament'. https://www.theccc.org.uk/ wp-content/uploads/2020/06/Reducing-UK-emissions-Progress-Report-to-Parliament-Committee-on-Cli.._-002-1.pdf [Accessed 31 August 2021].

Coulomb, R. and Henriet, F. (2018), 'The Grey Paradox: How fossil-fuel owners can benefit from carbon taxation', Journal of Environmental Economics and Management, 87, pp. 206-23.

Cuadra, G. and Sapriza, H. (2008), 'Sovereign default, interest rates and political uncertainty in emerging markets', Journal of International Economics, 76, 1, pp. 78-88.

Dasgupta, S., van Maanen, N., Gosling, S.N., Piontek, F., Otto, C. and Schleussner, C.F. (2021), 'Effects of climate change on combined labour productivity and supply: An empirical, multi-model study', The Lancet Planetary Health, 5, 7, pp. e455-65.

Day, E., Fankhauser, S., Kingsmill, N., Costa, H. and Mavrogianni, A. (2019), 'Upholding labour productivity under climate change: An assessment of adaptation options', Climate Policy, 19, 3, pp. 367-85.

Dechezlepretre, A., Martin, R. and Mohnen, M. (2014), Knowledge Spillovers from Clean and Dirty Technologies, London: Centre for Economic Performance, London School of Economics and Political Science. 
Dell'Ariccia, G., Ferreira, C., Jenkinson, N., Laeven, L., Martin, A., Minoiu, C. and Popov, A. (2018), 'Managing the sovereign-bank nexus', ECB Working Paper 2177, European Central Bank, Frankfurt.

Dietz, S. and Stern, N. (2015), 'Endogenous growth, convexity of damages and climate risk: How Nordhaus' framework supports deep cuts in carbon emissions', Economic Journal, 125, 583, pp. 574-620.

Dietz, S., Bowen, A., Dixon, C. and Gradwell, P. (2016), 'Climate value at risk of global financial assets', Nature Climate Change, 6, 7, pp. 676-679.

Dunne, J.P., Stouffer, R.J. and John, J.G. (2013), 'Reductions in labour capacity from heat stress under climate warming', Nature Climate Change, 3, 6, pp. 563-6.

Ekins, P. and Zenghelis, D. (2021), 'The costs and benefits of environmental sustainability,' Sustainability Science, 16, pp. 949-65.

Farhi, E. and Gabaix, X. (2016), 'Rare disasters and exchange rates,' Quarterly Journal of Economics, 131, 1, pp. 1-52.

Farhi, E. and Tirole, J. (2018), 'Deadly embrace: Sovereign and financial balance sheets doom loops', Review of Economic Studies, 85(3), pp. 1781-823.

Gaspar, V., Mauro, P., Pattillo, R. and Espinoza, C. (2020), 'Public investment for the recovery', IMF Blog, 5 October. https:// blogs.imf.org/2020/10/05/public-investment-for-the-recovery/ [Accessed 31 August 2021].

Gennaioli, N., Martin, A. and Rossi, S. (2018), 'Banks, government bonds, and default: What do the data say?', Journal of Monetary Economics, 98, 98-113.

Global Commission on Adaptation (2019), Adapt Now: A Global Call for Leadership on Climate Resilience, Washington, DC: The New Climate Economy.

Haldane, A. (2021), 'Inflation: A tiger by the tail?'. Speech by Andy Haldane. Bank of England, February 26. https:// www.bankofengland.co.uk/speech/2021/february/andy-haldane-recorded-mini-speech-on-inflation-outlook [Accessed 31 August 2021].

Hepburn, C., O’Callaghan, B., Stern, N., Stiglitz, J. and Zenghelis, D. (2020), 'Will COVID-19 fiscal recovery packages accelerate or retard progress on climate change?', Oxford Review of Economic Policy, 36, S1, pp. S359-81.

Hicks, J. (1932), Theory of Wages, London: Macmillan \& Co.

Hidalgo, C.A., Klinger, B., Barabási, A.-L. and Hausmann, R. (2007), 'The product space conditions the development of nations', Science, 317, 5837, pp. 482-7.

Hochrainer-Stigler, S., Keating, A., Handmer, J. and Ladds, M. (2018), 'Government liabilities for disaster risk in industrialized countries: A case study of Australia', Environmental Hazards, 17, 5, pp. 418-35.

House of Commons (2021), 'Government borrowing, debt and debt interest: Historical statistics and forecasts', House of Commons Library Briefing Paper 05745, 27 May 2021. https://researchbriefings.files.parliament.uk/documents/SN05745/ SN05745.pdf [Accessed 04 October 2021].

IIF (2021), 'Global debt monitor. COVID drives debt surge-stabilization ahead?', February 17. https://www.iif.com/Portals/0/ Files/content/Global\%20Debt\%20Monitor_Feb2021_vf.pdf [Accessed 31 August 2021].

International Monetary Fund [IMF] (2020), Fiscal monitor, October 2020 - Policies for the Recovery. https://www.imf.org/en/ Publications/FM/Issues/2020/09/30/october-2020-fiscal-monitor [Accessed 31 August 2021].

IPBES (2019), 'Summary for Policymakers of the Global Assessment Report on Biodiversity and Ecosystem Services of the Intergovernmental Science-Policy Platform on Biodiversity and Ecosystem Services', https://ipbes.net/global-assessment.

Jaffe, A.M. (2020), 'Stranded assets and sovereign states', National Institute Economic Review, 251, pp. R25-36.

Jordà, Ò. and Taylor, A.M. (2016), 'The time for austerity: Estimating the average treatment effect of fiscal policy', The Economic Journal, 126, 590, pp. 219-55.

Kahn, M.E., Mohaddes, K., Ng, R.N.C., Pesaran, M.H., Raissi, M. and Yang, J.-C. (2021), 'Long-term macroeconomic effects of climate change: A cross-country analysis', Energy Economics, 104, pp. 105624/1-13.

Kalkuhl, M. and Wenz, L. (2020), 'The impact of climate conditions on economic production. Evidence from a global panel of regions,' Journal of Environmental Economics and Management, 103, p. 102360.

Kling, G., Lo, Y.C., Murinde, V. and Volz, U. (2018), 'Climate vulnerability and the cost of debt', Centre for Global Finance Working Paper 12/2018, SOAS University of London, London.

Kling, G., Volz, U., Murinde, V. and Ayas, S. (2021), 'The impact of climate vulnerability on firms' cost of capital and access to finance,' World Development, 137, p. 105131.

Klomp, J. and Valckx, K. (2014), 'Natural disasters and economic growth: A meta-analysis', Global Environmental Change, 26, pp. 183-95.

Klusak, P., Agarwala, M., Burke, M., Kraemer, M. and Mohaddes, K. (2021), 'Rising temperatures, falling ratings: The effect of climate change on sovereign creditworthiness', Bennett Institute Working Paper, University of Cambridge, Cambridge.

Koetsier, I. (2017), 'The fiscal impact of natural disasters', Tjalling C. Koopmans Research Institute Discussion Paper 17-17, Utrecht University, Utrecht.

Kotz, M., Wenz, L., Stechemesser, A., Kalkujl, M. and Levermann, A. (2021), 'Day-to-day temperature variability reduces economic growth', Nature Climate Change, 11, pp. 319-25.

Licht, A. (2008), 'Social norms and the law: Why peoples obey the law,' Review of Law \& Economics, 4, 3, pp. 715-50. 
Liebreich (2018), 'Scenarios for a solar singularity', LinkedIn, December 22. https://www.linkedin.com/pulse/scenarios-solarsingularity-michael-liebreich/ [Accessed 31 August 2021].

Martin, R., Unsworth, S., Valero, A. and Verhoeven, D., (2020), 'Innovation for a strong and sustainable recovery', Centre for Economic Performance, Covid Analysis Series, No. 14, London School of Economics and Political Science.

McGlade, C. and Ekins P. (2015), 'The geographical distribution of fossil fuels unused when limiting global warming to $2{ }^{\circ} \mathrm{C}$,' Nature, 517, 7533, pp. 187-90.

Mealy, P. and Teytelboym, A. (2021), 'Economic complexity and the green economy,' Research Policy, p. 103948.

Mercure, J.F., Chester, D., Lynch, C., Jarvis, S. and Jarvis, A. (2021). 'Stranded human and produced capital in a net-zero transition', Research Square; doi:10.21203/rs.3.rs-644993/v1.

Mitchell, T., Mechler, R. and Peters, K. (2014), 'Placing disaster risk management at the heart of national economic and fiscal policy', in Markandya, A., Galarraga, I. and de Murieta, E.S. (eds), Handbook on the Economics of Adaptation, London: Routledge, pp. 417-36.

Monasterolo, I. (2020), 'Climate change and the financial system', Annual Review of Resource Economics, 12, 1, pp. $299-320$.

New Climate Economy (2018), 'Unlocking the inclusive growth story of the $21^{\text {st }}$ century: Accelerating climate action in urgent times', https://newclimateeconomy.report//2018 [Accessed 31 August 2021].

NGFS (2019), A Call for Action: Climate Change as a Source of Financial Risk, Paris: Central Banks and Supervisors Network for Greening the Financial System.

NOAA (2021), 'Billion-dollar weather and climate disasters: Overview'. https://www.ncdc.noaa.gov/billions/ [Accessed 31 August 2021].

OBR (2021), 'Office for budget responsibility fiscal risks report', July 2021. https://obr.uk/docs/dlm_ uploads/Fiscal_risks_report_July_2021.pdf.

OPEC (2019), 'Who gets what from a litre of oil in 2018', OPEC Annual Statistical Bulletin 2019. https://www.opec.org/opec web/en/data_graphs/333.htm [Accessed 31 August 2021].

Ostrom, E. (2000), 'Collective action and the evolution of social norms', Journal of Economic Perspectives, 14, 3, pp. 137-58.

Our World in Data (2021), 'Why did renewables become so cheap so fast?'. https://ourworldindata.org/cheap-renewablesgrowth [Accessed 31 August 2021].

Persson, T.A., Azar, C., Johansson, D. and Lindgren, K. (2007), 'Major oil exporters may profit rather than lose, in a carbonconstrained world', Energy Policy, 35, 12, 6346-53.

Pfeiffer, A., Millar, R., Hepburn, C., Beinhocker, E., (2016), 'The " $2{ }^{\circ} \mathrm{C}$ capital stock" for electricity generation: Committed cumulative carbon emissions from the electricity generation sector and the transition to a green economy', Applied Energy, 179, pp. 1395-408; doi:10.1016/j.apenergy.2016.02.093.

Posner, R.A. (1997). 'Social norms and the law: An economic approach,' American Economic Review, 87, 2, pp. 365-69.

Rachel, L. and Smith, T.D. (2015). 'Secular drivers of the global real interest rate', Bank of England Staff Working Paper 571, Bank of England, London.

Robins, N., Gouldson, A., Irwin, W., Sudmant, A. and Rydge, J. (2019), Financing Inclusive Climate Action in the UK: An Investor Roadmap for the Just Transition, London: London School of Economics and Political Science.

Rydge, J., Martin, R. and Valero, A. (2018), 'Sustainable growth in the UK, Seizing opportunities from technological change and the transition to a low-carbon economy', LSE Growth Commission. http://www.lse.ac.uk/GranthamInstitute/wpcontent/uploads/2018/12/Sustainable-Growth-in-the-UK_Full-Report_78pp.pdf [Accessed 31 August 2021].

Schuler, P., Oliveira, L.E., Mele, L.E. and Antonio, M. (2019), 'Managing the fiscal risks associated with natural disasters', in Pigato, M.A. (ed), Fiscal Policies for Development and Climate Action, Washington, DC: World Bank, pp. 133-54.

Semieniuk, G., Campiglio, E., Mercure, J.F., Volz U. and Edwards, N. (2021), 'Low-carbon transition risks for finance,' Wiley Interdisciplinary Reviews: Climate Change, 12, 1, p. e678.

Stern, N. (2007), The Economics of Climate Change, West Nyack: Cambridge University Press.

Stern, N., Unsworth, S., Valero, A., Zenghelis, D., Rydge, J. and Robins, N. (2020), 'Strategy, investment and policy for a strong and sustainable recovery: An action plan', Paper Number CEP COVID-19-005, Centre for Economic Performance, London School of Economics and Political Science, London.

Stern, N. and Valero, A. (2021), 'Innovation, growth and the transition to net-zero emissions', Research Policy, 50, 9, p. 104293.

Stern, N. and Zenghelis, D. (2021), 'Fiscal responsibility in advanced economies through investment for economic recovery from the COVID-19 pandemic', Grantham Research Institute on Climate Change and the Environment, London.

Task Force on Climate-Related Financial Disclosures [TCFD] (2017), 'Recommendations of the Task Force on Climate-related Financial Disclosures’. https:/assets.bbhub.io/company/sites/60/2020/10/FINAL-2017-TCFD-Report11052018.pdf [Accessed 31 August 2021].

UK Climate Change Committee (2021), 'Sixth Carbon Budget', December 9. https://www.theccc.org.uk/publication/sixthcarbon-budget/ [Accessed 31 August 2021].

Van der Meijden, G. and Smulders, S. (2017), 'Carbon lock-in: The role of expectations', International Economic Review, $\mathbf{5 8}, 4$, pp. 1371-415. 
Volz, U., Beirne, J., Ambrosio Preudhomme, N., Fenton, A., Mazzacurati, E., Renzhi, N. and Stampe, J. (2020), Climate Change and Sovereign Risk, London-Tokyo-Singapore-Berkeley: SOAS University of London, Asian Development Bank Institute, World Wide Fund for Nature Singapore, and Four Twenty Seven.

Watson, K.P., Cross, R. and Jones, M.P. (2021), 'The winter storm of 2021', Hobby School of Public Affairs, University of Houston. https://uh.edu/hobby/winter2021/storm.pdf [Accessed 31 August 2021].

Way, R., Ives, M., Mealy, P. and Farmer, J.D. (2021), 'Empirically grounded technology forecasts and the energy transition', INET Oxford Working Paper 2021-01.

Zenghelis, D. (2021a), 'Mind over matter', Bennett Institute, University of Cambridge. https://www.bennettinstitute.cam.ac. uk/blog/mind-over-matter-how-expectations-generate-wealth/.

Zenghelis, D. (2021b), 'Why sustainable, inclusive, and resilient investment makes for efficacious post-COVID medicine', Wiley Interdisciplinary Reviews: Climate Change, 12, p. e708; doi:10.1002/wcc.708.

Zenios, S.A. (2021), 'The risks from climate change to sovereign debt in Europe', SSRN Electronic Journal; doi:10.2139/ ssrn. 3891078 .

Cite this article: Agarwala, M., Burke, M., Klusak, P., Mohaddes, K., Volz, U. and Zenghelis, D. (2021), 'Climate change and fiscal sustainability: Risks and opportunities', National Institute Economic Review, 258, pp. 28-46. https://doi.org/ 10.1017/nie.2021.37 